\title{
Uji Toksisitas Daun Kelor ( Moringa oleifera) Terhadap Sel Fibroblas Gingiva Menggunakan Uji MTT assay
}

\author{
( TOXICITY OF KELOR LEAVES (Moringa oleifera) AGAINST GINGIVAL \\ FIBROBLAST USING MTT ASSAY)
}

\author{
Sheila Ayu Nararya ${ }^{1}$, Edhi Jularso ${ }^{2}$, Theresia Indah Budhy ${ }^{2}$ \\ ${ }^{1}$ Mahasiswa Pendidikan Dokter Gigi \\ ${ }^{2}$ Staf Pengajar Departemen Patologi Mulut \& Maksilofasial \\ Fakultas Kedokteran Gigi Universitas Airlangga \\ Surabaya - Indonesia \\ e-mail : sheila.nararya@ymail.com
}

\begin{abstract}
Background: The oral cavity's health is one of the most important factors in determining the quality of human life. Oral cancer is a type of disease that can fataly change the quality of human life if not properly handle. Among all the cancer treatment, chemotherapy is oftenly done. However, chemotherapy has some side effects that can exacerbate the patient's state. Alternative care has become another promising option besides chemotherapy. One of them is Moringa oleifera or as known as kelor leaves. The active compound content of Moringa oleifera extract especially isothiocianate has good potential in cancer therapy. But, any materials used in human care must passed the toxicity test. Purpose: This research was conducted to find out the toxicity of Moringa oleifera extract with isothiocianate to primary cell gingival fibroblast.Method: Experimental laboratory study with the post test only group control design. There are 4 types of concentration group from kelor leaves extract which is 3,125\%,1,625\%,0,812\%, and 0,406\% and there are also the media control and cell control. Each sample were put in 96 well that already contain fibroblast cell culture with 6 times replication for each group. And then, it was tested with MTT assay. Results: The concentration group from 3,125\% until 0,406\% has the percentage of living cells above 100\%. Conclusion: The results of this research is that the kelor leaves (Moringa oleifera) extract with isothiocyanate is not toxic against primary cell culture fibroblast.
\end{abstract}

Keywords: Moringa oleifera extract, isothiocyanate, toxicity.

Latar Belakang: Kesehatan rongga mulut merupakan salah satu faktor penting yang berperan dalam menentukan kualitas hidup manusia. Kanker rongga mulut merupakan salah satu penyakit yang dapat mengubah kualitas hidup manusia dan berkaibat fatal apabila tidak ditangani dengan tepat. Salah satu pengobatan kanker yang sering dilakukan adalah kemoterapi. Meskipun demikian, kemoterapi memiliki beberapa efek samping yang dapat berakibat buruk kepada pasien kanker. Perawatan alternatif pun menjadi pilihan lain selain kemoterapi. Salah satunya adalah dengan daun kelor (Moringa oleifera). Kandungan aktif dari daun kelor memiliki manfaat yang baik sebagai terapi kanker. Namun, semua bahan yang akan digunakan pada manusia harus melawati uji toksisitas. Tujuan: Tujuan dilakukan penelitian ini yaitu untuk mengetahui hasil toksisitas ekstrak daun kelor (Moringa oleifera) dengan kandungan isotiosianat terhadap cell line fibroblas. Metode: Penelitian eksperimental laboratoris dengan post test only group design. Terdapat 4 macam kelompok konsentrasi dari ekstrak daun kelor yaitu 3,125\%,1,625\%,0,812\%, dan 0,406\% disertai dengan kontrol media dan kontrol sel. Setiap perlakuan diletakkan pada plate 96 well yang telah berisi kultur sel fibroblas dengan 6 kali replika untuk setiap kelompok. Kemudian dilakukan uji MTT assay. Hasil: Kelompok konsentrasi 3,125\% hingga $0,812 \%$ memiliki jumlah persentase sel hidup diatas 100\%. Kesimpulan: Hasil penelitian ini 
menunjukkan bahwa ekstrak daun kelor (Moringa oleifera) dengan kandungan isotiosianat tidak bersifat toksik terhadap kultur sel primer fibroblas.

\section{Kata Kunci : Ekstrak daun kelor (Moringa oleifera), isotiosianat, uji toksisitas.}

\section{PENDAHULUAN}

Pada era yang telahg maju kini kesehatan merupakan salah satu faktor penting yang berperan dalam kehidupan manusia. Hal ini menyebabkan manusia terfokus pada kesehatan tubuhnya, kesehatan rongga mulut mereka sering kali diabaikan. Kesehatan rongga mulut juga merupakan salah satu faktor penting yang berperan dalam menentukan kualitas hidup menusia. Salah satu penyakit yang dapat berakibat fatal dikarenakan tidak menjaga kesehatan dari tubuh kita termasuk rongga mulut adalah kanker.

Prevalensi penyakit kanker pada tahun 2012 tercatat 369,200 kasus. Dengan rata - rata insidensi tertinggi terdapat di Asia Tenggara ${ }^{9}$.

Kanker sampai saat ini merupakan penyakit yang pengobatannya masih belum tuntas. Pengobatan untuk kanker yang sering dilakukan salah satunya adalah kemoterapi. Kemoterapi sendiri memiliki beberapa kelemahan selain biaya yang cukup mahal dan berbagai macam efek samping seperti pusing, mual, kelelahan, mucosistis, kerusakan pada saraf, neutropenia, serta infeksi dapat terjadi pada pasien setelah menjalani kemoterapi ${ }^{18}$.

Pengobatan berbahan baku herbal pun menjadi pilihan masyrakat dalam upaya mengobati kanker dikarenakan biaya yang cukup murah, mudah mendapatkan dan efek samping yang diakibatkan sedikit. Salah satu produk pengobatan herbal adalah Biocurkem. Biocurkem mengandung ekstrak alami curcuma longa (kunyit) yang terstandarisasi dan telah dipatenkan. Biocurkem juga mengandung curcuminoid dan minyak atsiri sesquiterpene. Biocurkem memiliki mekanisme kerja yaitu menghambat transformasi, proliferasi, dan invasi sel kanker. Sebagai terapi untuk kanker, Biocurkem relatif aman. Namun, Biocurkem memiiliki bioavailabilitas yang rendah. Lebih dari $75 \%$ curcuma diekskresikan melalui feses dan sebagian kecil urin, sehingga jumlah yang diabsorpsi sangat rendah. Akibatnya efek terapi yang diharapkan tidak tercapai dan membutuhkan waktu yang lama ${ }^{29}$.

Inovasi lain terhadap pengobatan alternatif pun dikembangkan. Salah satunya adalah Moringa oleifera atau yang lebih dikenal dengan sebutan tanaman kelor. Tanaman kelor merupakan salah satu tanaman dari spesies Moringaceae yang pendistribusiannya telah dikenal di seluruh dunia.
Di Indonesia, tanaman kelor telah banyak dibiakkan dan mudah didapat ${ }^{20}$.

Tanaman kelor (Moringa oleifera) merupakan tanaman yang kaya akan nutrisi. Kandungan nutrisi tersebut tersebar pada seluruh bagian tanaman kelor, mulai dari daun, kulitm batang, bunga, buah (polong), sampai akarnya. Tanaman kelor ini mengandung lebih banyak vitamin, mineral, antioksidan, asam amino esensial, dan senyawa lain yang bermanfaat ${ }^{14}$.

Pada bagian daunnya memiliki kandungan senyawa glukosinolat dan isotiosianat yang diketahui sebagai hipotensif, anti kanker, penghambat aktivitas bakteri, dan jamur ${ }^{4}$.

Isotiosianat sebagai anti kanker memiliki mekanisme yaitu mampu menginduksi apoptosis dan menginhibisi pertumbuhan sel kanker melalui fase $\mathrm{G} 2 / \mathrm{M}$ cell cycle arrest ${ }^{28}$. Apoptosis merupakan proses kematian sel yang memiliki tujuan untuk membunuh sel yang berbahaya dan menjadi ancaman bagi sel tubuh lainnya ${ }^{3}$. Fase G2/M cell cylce arrest merupakan fase dimana DNA yang mengalamu kerusakan ditangkap agar tidak terjadi pembelahan yang dapat merusak sel tubuh ${ }^{16}$. Sedangkan untuk kandungan seperti flavonoid, asam askorbat, dan karetenoid memiliki manfaat sebagai antioksidan ${ }^{14}$.

Kandungan - kandungan tersebut memang memiliki potensi yang baik akan tetapi setiap bahan yang digunakan pada manusia haruslah tidak merugikan atau tidak memiliki efek toksik. Terlebih lagi apabila bahan tersebut memiliki tujuan untuk dijadikan pengobatan alternatif yang bersifat kuratif dan preventif. Diperlukan adanya suatu uji untuk mengukur sifat toksik dari bahan tersebut. Untuk mengukur sifat toksik suatu bahan terhadap sel dapat dilakukan melalui uji toksisitas ${ }^{7}$. Telah dilakukan penelitian sebelumnya dengan konsentrasi ekstrak 50\%, 25\%, 12,5\%, dan 6,25\% yang menunjukkan hasil penelitian bersifat toksik. Maka dari itu, konsentrasi ekstrak 3,125\%, 1,625\%, $0,812 \%$, dan $0,406 \%$ dikarenakan range konsentrasi tersebut merupakan range konsentrasi yang cukup rendah untuk digunakan dalam uji toksisitas terhadap fibroblast gingiva manusia.

Berdasarkan hal tersebut, penulis ingin meneliti lebih dalam tentang efek toksisitas daun kelor (Moringa oleifera).

\section{BAHAN DAN METODE}


Penelitian ini telah mendapat persetujuan kelaikan etik oleh HRECC FODM UNAIR dengan nomor sertifikat 196/HRECC,FODM/IX/2017. Jenis penelitian yang digunakan adalah eksperimental laboratoris dengan pendekatan randomized post test only control group design dengan besar replikasi sebanyak 6 kali dengan konsentrasi ekstrak daun kelor yaitu $3,125 \%, 1,625 \%, 0,812 \%$, dan $0,406 \%$ disertai dengan kontrol media dan kontrol sel. Setiap kelompok perlakuan diletakkan pada plate 96 well. Setiap kelompok konsentrasi ekstrak daun kelor diberi perlakuan dengan media dan sel. Pada kontrol media, hanya mengandung media saja yaitu medium alpha mem dan pada kontrol sel hanya mengandung sel fibroblas saja sebagai kontrol negatif.

\section{Pembuatan Ekstrak Daun Kelor}

Sebanyak 500 gram daun kelor segar dikeringkan dan dilembutkan dengan menggunakan blender, lalu dilakukan maserasi dengan ditambahkan pelarut etanol $96 \%$ dimasukkan ke dalam wadah, ditutup dan dibiarkan selama 2 hari dan terlindungi dari sinar matahari. Setelah itu, campuran tersebut disaring sehingga didapat maserat. Ampas dimaserasi dengan etanol 96\% menggunakan prosedur yang sama. Maserasi dilakukan sampai didapat maserat yang jernih. Maserat diuapkan dengan menggunakan alat penguap vakum putar pada suhu $40^{\circ} \mathrm{C}$. Ekstrak daun kelor selanjutnya dilakukan skrining fitokimia untuk mendeteksi senyawa aktif tumbuhan tersebut.

\section{Tahap Skrining Fitokimia Uji Glikosida}

\section{Larutan Percobaan}

Sari filtrat 3 kali, tiap kali dengan $20 \mathrm{~mL}$ campuran 3 bagian volume kloroform $\mathrm{P}$ dan 2 bagian volume isopropanolol $\mathrm{P}$. Pada kumpulan sari tambahkan natrium sulfatanhidrat $\mathrm{P}$, saring dan uapkan pada suhu tidak lebih dari 50'. Larutan sisa dengan $2 \mathrm{~mL}$ metanol P.

Tahap Percobaan

- Uapkan 0,1 mL larutan percobaan di atas tangas air, larutkan sisa dalam $5 \mathrm{~mL}$ asam asetat anhidrat P. Tambahkan 10 tetes asam sulfat $\mathrm{P}$, terjadi warna biru atau hijau menunjukkan adanya glikosida ( reaksi Liebermann Burchard )

- Masukkan 0,1 mL larutan percobaan dalam tabung reaksi, uapkan di atasa tangas air. Pada sisa tambahkan $2 \mathrm{~mL}$ air dan 2 tetes Molish LP. Tambahkan $2 \mathrm{~mL}$ asam sulfat $\mathrm{P}$, terbentuk cincin berwarna ungu pada batas cairan, menunjukkan adanya ikatan gula ( reaksi Molish )

\section{Tahap Isolasi Sel Fibroblas}

Sampel gingiva yang telah diambil segera dicuci dengan menggunakan $\mathrm{NaCl} /$ Aquadest, kemudian dilakukan pencucian kembali menggunakan media yang juga terdapat antibiotik. Pencucian dilakukan selama 5 menit. Sampel diiris dan dihaluskan menggunakan gunting bedah sebelum diberi enzim tripsin. Sampel dimasukkan ke dalam tabung erlenmeyer yang didalamnya telah terdapat magnetic bar dan diberikan enzim tripsin sebanyak $5 \mathrm{ml}$ menggunakan pipet filler. Tabung diletakkan pada magnetic stirer with heater 37 derajat celcius selama 45 menit. Setelah 45 menit, dilakukan pemberian stopper $5 \mathrm{ml}$ (dengan perbandingan stopper : enzim tripsin 1:1 ) untuk menghentikan kerja enzim tripsin. Kemudian, tabung diletakkan kembali pada magnetic stirer with heater selama 15 menit. Supernatan yang terdapat di dalam tabung erlenmeyer dituang ke dalam conical tube pertama, kemudian endapan yang berisi banyak jaringan dituang ke dalam conical tubekedua. Kedua conical tube dimasukkan ke alat sentrifugasi selama 5-6 menit dengan kecepatan 1800 rpm hingga sel mengendap. Kemudian media dibuang dan diambil endapannya. Pada setiap conical tube diberi media sebanyak 5 $\mathrm{ml}$ bertujuan mencuci sisa enzim agar hilang dan dilakukan sentrifugasi selama 5-6 menit dengan kecepatan $1800 \mathrm{rpm}$. Kemudian media dibuang dan diambil endapannya saja. Kedua conical tube diberi media sebanyak $5 \mathrm{ml}$, kemudian campuran media dan sel di dalam conical tube diambil menggunakan pipet filler dan ditaruh dalam plate. Plate diletakkan dalam inkubator dengan suhu 37 derajat celcius hingga sel tumbuh. Dilakukan pencucian setiap 3-4 hari dan ditanam kembali agar sel mendapat nutrisi yang cukup.

\section{Tahap Splitting / Pasase Sel}

Media (5mm) harus dibuang terlebih dahulu. Kemudian plate dicuci menggunakan Phosphate Buffer Saline (PBS) untuk mencuci sisa media yang masih menempel pada plate. Apabila media masih tersisa akan mempersulit terlepasnya sel dari dasar plate. Karena media mengandung serum yang dapat mempengaruhi kerja enzim tripsin. Kemudian, sel dicuci menggunakan enzim tripsin untuk melepaskan sel yang menempel di dasar plate. Sel yang telah diberi enzim tripsin dan di inkubasi selama 3-5 menit. Setelah 5 menit, diberi tripsin lagi untuk sel yang masih belum terlepas. Sel yang sudah terlepas diberikan medium alpha MEM dan dijadikan single cell. Serum atau media berfungsi 
untuk menghentikan kerja tripsin agar tidak berlebihan. Kemudian dilakukan inkubasi selama 5 menit. Proses pelepasan sel dilakukan 2-3 kali karena sel masih sangat baru. Proses spliting sel dilakukan hingga mendapatkan sel fibroblast murni dengan melakukan proses peremajaan sel. Apabila tidak dilakukan proses spliting sel, pertumbuhan sel tidak sesuai dan berdempetan sehingga sel cepat tua dan mudah mati. PBS dimasukkan sebanyak 2,5 $\mathrm{mL}$ untuk memisahkan atau membuang media dalam kultur, kemudian diberi enzim tripsin sebanyak $2 \mathrm{~mL}$ untuk melepaskan sel dalam media dan diinkubasi pada suhu 37 derajat celcius, kadar $\mathrm{CO}_{2} 5 \%$ selama 5 menit. Dilakukan pengamatan untuk memastikan semua sel sudah terlepas dan diambil menggunakan pipet serta diinkubasi selama 5 menit. Sel yang telah terlepas diberi medium alpha MEM dan tripsin dengan perbandingan 1:1 (masing-masing $2 \mathrm{~mL}$ ). Kemudian, cairan dimasukkan ke dalam conical tube sehingga sel akan menempel di dinding tube. Dilakukan beberapa kali pencucian dengan menggunakan tripsin dan alpha MEM sehingga sel monolayer menjadi single cell dalam conical tube. Kemudian, dilakukan sentrifugasi $1800 \mathrm{rpm}$ selama 5 - 6 menit. Media dan enzim dibuang menggunakan pipet, kemudian diberi alpha MEM kembali hingga $50 \mathrm{~mL}$. Dilakukan proses vibrating menggunakan tube mixer dan sel dibagi dalam microplate 96 well sebanyak 100 ldengan kepadatan $3-5 \times 10^{3}$ dan diinkubasi selama 24 jam dengan suhu $37^{\circ}$.

\section{Tahap Pelakuan pada Kultur Sel Fibroblas}

Mengamati microplate yang berisi sel fibroblast yang telah diinkubasi dibawah mikroskop cahaya untuk memastikan sel fibroblast yang ditanam dalam setiap well atau sumuran cukup banyak untuk penelitian. Sel fibroblast yang sudah didistribusikan dalam sumuran dibagi dalam 6 kelompok perlakuan, yaitu kelompok 1 sebagai kontrol negatif (kontrol sel ), kelompok 2 sebagai kontrol media, kelompok 3 dengan perlakuan dengan paparan ekstrak daun kelor (Moringa oleifera) konsentrasi 3,125\%, kelompok 4 dengan perlakuan dengan paparan ekstrak daun kelor (Moringa oleifera) konsentrasi 1,625\%, kelompok 5 dengan perlakuan dengan paparan ekstrak daun kelor (Moringa oelifera) konsentrasi 0,812\%, kelompok 6 dengan perlakuan dengan paparan ekstrak daun kelor (Moringa oleifera) konsentrasi $0,406 \%$. Setiap perlakuan mempunyai replika 6 well atau sumuran. Setelah itu, memberikan perlakuan setiap 6 replika/ sumuran pada kelompok 3 dengan perlakuan dengan paparan ekstrak daun kelor (Moringa oleifera) konsentrasi 3,125\%, kelompok 4 dengan perlakuan dengan paparan isotiosianat konsentrasi 1,625\%, kelompok 5 dengan perlakuan dengan paparan isotiosianat konsentrasi $0,812 \%$, kelompok 6 dengan perlakuan dengan paparan isotiosianat konsentrasi $0,406 \%$.

\section{Tahap Pengamatan dan Pembacaan Hasil Penelitian}

Garam MTT dilarutkan dalam PBS (Phospate Buffer Saline) $5 \mathrm{mg} / \mathrm{ml}$. Media sel dibuang, kemudian dicuci dengan PBS dan MTT ditambahkan secara langsung pada palte yang berisi medium kultur sebanyak $10 \mu L$. Inkubasi kembali selama \pm 4 jam pada suhu $37^{0} \mathrm{C}$. Seluruh media dalam well atau sumuran dan bahan uji diambil dan setiap well atau sumuran ditambahkan DMSO sebanyak $50 \mu \mathrm{L}$. Plate diaduk secara mekanis menggunakan plate shaker sampai Kristal formazon terlarut selama 5 menit. Sel fibroblast yang hidup terwarnai dengan formazon menjadi biru, sedangkan yang mati tidak terbentuk warna biru. Formazon dibaca absorbansinya secara spektrofotometri menggunakan ELISA reader dengan panjang gelombang $620 \mathrm{~nm}$. Semakin pekat warnanya, maka semakin tinggi nilai absorbansinya dan semakin banyak jumlah sel hidup.

\section{Hasil}

Berdasarkan hasil pengamatan dan pembacaan nilai absorbansi atau optical density uji toksisitas ekstrak daun kelor dengan konsentrasi 3,125\%, $1,625 \%, 0,812 \%$, dan $0,406 \%$ terhadap sel fibroblas gingiva didapatkan hasil sebagai berikut

\begin{tabular}{llll}
\hline Konsentrasi & $\begin{array}{l}\text { Rerata } \\
\text { Absorbansi }\end{array}$ & $\begin{array}{c}\text { \% Sel } \\
\text { Hidup }\end{array}$ & $\begin{array}{l}\text { Standar } \\
\text { Deviasi }\end{array}$ \\
\hline $3,125 \%$ & 0,680 & $103,8 \%$ & 1,05028787 \\
$1,625 \%$ & 0,674 & $103 \%$ & 2,75286 \\
$0,812 \%$ & 0,662 & $101 \%$ & 1,36571825 \\
$0,406 \%$ & 0,654 & $100 \%$ & 0,48733774 \\
\hline
\end{tabular}

Tabel 1. Rerata absorbansi dan standar deviasi proliferasi sel fibroblas setelah perlakuan

Dari data hasil penelitian yang didapatkan kemudian dilakukan perhitungan statistik. Sebelum 
dilakukan uji dan analisis antar kelompok terlebih dahulu dilakukan uji normalitas menggunakan uji Shapiro-Wilk. Pada penelitian ini seluruh kelompok konsentrasi menunjukkan distribusi data yang normal kecuali pada konsentrasi 1,625\%. Dikarenakan $\mathrm{P}=0,009 \quad(\mathrm{P}<0,05) \quad$. Kemudian dilakukan uji homogenitas varian data menggunakan Levenne-Test dengan hasil $\mathrm{P}=0,129$ $(\mathrm{P}>0,05)$ yang menunjukkan data tersebut homogen. Dilanjutkan dengan uji Kruskall-Wallis Test untuk melihat perbedaan signifikansi keseluruhan dari kelompok perlakuan. Dari hasil uji Kruskall-Wallis Test dihasilkan $\mathrm{P}=0,011$ $(\mathrm{P}<0,05)$ yang menunjukkan bahwa adanya perbedaan afektivitas yang signifikan antar kelompok perlakuan. Kemudian dilakukan uji Mann-Whitney Test untuk menentukan konsentrasi optimum dair ekstrak daun kelor

\begin{tabular}{lrllrl}
\hline $\begin{array}{l}\text { K.Sel } \\
\text { Konsentrasi }\end{array}$ & $\begin{array}{l}\text { K.Sel } \\
\text { Konsentrasi } \\
\mathbf{3 , 1 2 5 \%}\end{array}$ & $\begin{array}{l}\mathbf{1 , 6 2 5 \%} \\
\end{array}$ & $\begin{array}{l}\text { K.Sel } \\
\text { Konsentrasi } \\
\mathbf{0 , 8 1 2 \%}\end{array}$ & $\begin{array}{l}\text { K.Sel } \\
\text { Konsentrasi } \\
\mathbf{0 , 4 0 6 \%}\end{array}$ \\
\hline 0,025 & 0,200 & 0,261 & 0,574 \\
\hline
\end{tabular}

Tabel 2. Hasil Uji Signifkansi dengan MannWhitney Test

Dari hasil Tabel 2 menunjukkan bahwa pada konsentrasi $3,125 \%$ menghasilkan $\mathrm{P}=0,025$ $(\mathrm{P}<0,05)$ yang berarti konsentrasi $3,125 \%$ dapat dijadikan konsetrasi optimum pada ekstrak daun kelor.

Hasil penelitian pada konsentrasi 3,125\% menunjukkan gambaran sel fibroblas yang semakin banyak setelah dilakukan uji MTT assay.

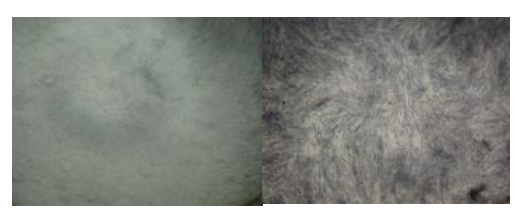

Gambar 1. Lapang pandang konsentrasi 3,125\% sebelum uji MTT assay(a) dan sesudah uji MTT assay (b)

\section{PEMBAHASAN}

Daun kelor (Moringa oleifera) merupakan daun yang memiliki kandungan kimia seperti polifenol, flavonoid, asam askorbat, dan isotiosianat. Kandungan kimia tersebut memiliki berbagai manfaat antara lain adalah sebagai antioksidan dalam tubuh, dapat menyebabkan kematian sel kanker (apoptosis), meningkatkan respon imun tubuh (kekebalan tubuh), perbaikan kerusakan DNA, dan menginhibisi aktivasi karsinogenesis. Terlepas dari manfaat tersebut, setiap bahan atau material dalam kedokteran gigi yang akan digunakan sebagai suatu perawatan atau pengobatan harus memenuhi syarat biokompatibel.

Suatu bahan atau material dapat dikatakan bersifat biokompatibel adalahapabila bahan tersebut tidak menyebabkan iritasi pada jaringan hidup, tidak menyebabkan respon toksik, bebas dari bahan yang dapat memicu reaksi alergi, dan tidak memiliki potensi karsinogenik. Dalam menentukan biokompatibel suatu bahan atau material dapat dilakukan melalui uji biokompatibilitas atau uji toksisitas. Pada tingkat pertama uji biokompatibiltas suatu bahan dapat dilakukan secara in vitro yaitu bahan material yang akan diuji dikontakkan diluar tubuh mikroorganisme seperti kultur sel ${ }^{2}$.

Pada penelitian ini uji toksisitas in vitro dilakukan dengan metode uji enzimatik (kolorimetri) yang menggunakan pereaksi MTT (Methyl Tiazolydiphenyl Tetrabromide) assay. Uji ini digunakan untuk mengukur kemampuan sel hidup berdasarkan aktivitas mitokondria sel ${ }^{8}$.

Sel fibroblas gingiva ini berasal dari gingiva manusia. Kultur sel dapat berupa kultur sel primer maupun cell line. Kultur sel primer merupakan kultur yang dimulai dari sel,jaringan, organ yang diperoleh langsung dari organisme asalnya. Kultur sel primer ini hanya dapat dipertahankan dalam periode waktu tertentu ${ }^{19}$. Kultur sel primer memiliki sifat yang lebih sensitif dibandingkan dengan cell lines. Pada uji in vitro lebih ideal menggunakan kultur sel primer.

Pengamatan uji toksisitas merupakan indikator untuk mengetahui pengaruh konsentrasi terhadap suatu substansi. Hasil penelitian menunjukkan pada konsentrasi ekstrak daun kelor (Moringa oleifera) sebesar $3,125 \%$ memiliki persentase sel hidup $103,8 \%$, pada konsentrasi $1,625 \%$ memiliki persentase sel hidup $103 \%$, pada konsentrasi $0,812 \%$ memiliki persentase sel hidup $101 \%$ dan pada konsentrasi $0,406 \%$ memiliki persentase sel hidup $100 \%$. Dari data tersebut dapat ditunjukkan bahwa ekstrak daun kelor memiliki sifat biokompatibel. Karena, persentase sel hidup mencapai diatas lethal concentration yaitu $50 \%$. Lethal concentration 50\%(LC50)merupakan konsentrasi perkiraan, dalam lingkungan percobaan yang terpapar yang akan membunuh $50 \%$ dari populasi dibawah kondisi yang ditentukan dari tes $^{24}$.

Data hasil penelitian ini diuji kenormalitasannya dengan menggunakan uji Shapiro Wilk. Dapat diketahui bahwa hasil distribusi data dari 
konsentrasi 3,125\%, 0,812\%, dan 0,406\% memiliki p>0,05 sehingga menunjukkan bahwa distribusi data tersebut normal. Hanya pada konsentrasi $1,625 \%$ yang memiliki $\mathrm{p}<0,05$ yang menunjukkan bahwa distribusi data pada konsentrasi tersebut tidak normal. Hal ini dapat terjadi dikarenakan adanya angka yang menyimpang pada kelompok konsentrasi $1,625 \%$ pada replika ke-3. Homogenitas varian data dari penelitian ini diuji menggunakan Levenne Test. Dari uji terebutmenunjukkan hasil yang homogen yaitu $\mathrm{p}=$ $0,129$ ( $p>0,05)$. Uji perbedaan signifkansi dari semua kelompok perlakuan secara keseluruhan diuji menggunakan Kruskall-Wallis Test. Hasil uji Kruskall-Wallis Test menunjukkan hasil yang signifikan dengan $\mathrm{p}=0,011(\mathrm{p}<0,05)$ yang artinya menunjukkan bahwa ada perbedaan efektivitas yang signifikan antar kelompok konsentrasi. Berikutnya data diuji menggunakan Mann-Whitney Test untuk menentukan konsentrasi optimum pada ekstrak daun kelor (Moringa oleifera).Hasil uji menunjukkan bahwa konsentrasi 3,125\% memiliki data yang signifikan yaitu $\mathrm{p}=0,025(\mathrm{p}<0,05)$. Sehingga, data tersebut dapat dijadikan pedoman konsentrasi optimum pada ekstrak daun kelor (Moringa oleifera).

Hal tersebut juga dapat terlihat dari hasil persentase sel hidup dari semua kelompok kosentrasi. Pada konsentrasi 3,125\% memiliki persentase sel hidup yang paling tinggi yaitu $103,8 \%$. Persentase proliferasi sel hidup pada tiap tingkat pengeceran memang tidak jauh berbeda. Namun, ada kecenderungan pada konsentrasi ekstrak awal memiliki hasil proliferasi sel lebih besar daripada hasil proliferasi sel pada tingkat pengeceran selanjutnya. Hal tersebut dapat disebabkan karena semakin sering dilakukan pengenceran pada suatu ekstrak maka akan mengurangi kandungan kimia dalam ekstrak tersebut dan menyebabkan jumlah perbandingan kandungan kimia pada ekstrak tersebut lebih kecil daripada kandungan dari media pada well.

Kandungan aktif dari daun kelor terutama isotiosianat memiliki sifat dapat merangsang enzim detoksifikasi seperti glutathione Stransferase yang berfungsi mengkonjugasi zat - zat xenobiotik menjadi GSH (Gluthatione) dan akhirnya mendetoksifikasi lingkungan seluler(Veal et al,2002). Dari detoksifikasi lingkungan seluler atau melalui aktivitas antioksidan yang mampu memblokir inisiasi dari susunan radikal bebas dapat mengakibatkan terbentuknya transforming growth factor $\beta$ sehingga menstimulasi proliferasi fibroblas ${ }^{13}$.

Antioksidan merupakan suatu senyawa yang dapat menangkal dampak negatif oksidan dengan cara mendonorkan satu elektronnya kepada senyawa yang bersifat oksidan tersebut sehingga aktivitas senyawa oksidan dapat dihambat. Antioksidan juga dapat menghambat reaksi oksidasi dengan cara mengikat radikal bebas dan molekul reaktif sehingga kerusakan sel dapat dicegah. Kerusakan sel akibat reaktivitas radikal bebas merupakan salah satu pemicu kanker. Hal tersebut terjadi karena interaksi senyawa oksigen reaktif (ROS) dengan DNA mengawali terbentuknya DNA adducts (ikatan DNA dengan karsinogen) selama proses perbaikan atau replikasi, yang berakibat terjadinya mutasi DNA. Penumpukan DNA termutasi dapat menyebabkan terjadinya perkembangan sel neoplastis ${ }^{25}$.

Dari penelitian ini dapat disimpulkan bahwa ekstrak daun kelor (Moringa oleifera) menunjukkan sifat biokompatibel pada konsentrasi mulai dari $3,125 \%$ hingga $0,406 \%$. Data konsentrasi efektif yang telah diuji tersebut dapat memberikan informasi bahwa konsentrasi ekstrak daun kelor bersifat non toksik dan aman digunakan sebagai pengobatan herbal.

\section{DAFTAR PUSTAKA}

1. Aminah, S, Ramdhan, $\mathrm{T}$, \& Yanis, $\mathrm{M}$, 2015, Kandungan Nutrisi dan Sifat Fungsional Tanaman Kelor (Moringa oleifera), Buletin Pertanian Perkotaan Vol 5, pp.37-39

2. Anusavice, KJ, 2013, Phillips' Science of Dental Materials, 12th ed, Elsevier Saunders, Missouri, pp. 150

3. Andrianus, Edmondo, 2014, Potensi Ekstrak Daun Rumput Mutiara (Hedyotis corymbosa (L) Lamk) terhadap Apoptosis Sel Kanker Rongga Mulut pada Tikus Wistar Jantan yang diinduksi Benzo(A)pirene, Skripsi,Fakultas Kedokteran Gigi Universitas Airlangga, pp.10-11

4. Anwar, F, Latif, S, \& Ashraf, M, 2007, Moringa oleifera : A Food Plant with Multiple Medicinal Uses, Wiley Interscience, pp.20-21.

5. Bose, CK, 2007, Possible role of Moringa Oleifera $L$. root in epithelial ovarian cancer, MedGenMed, pp.4-5

6. Barrientos, S, Stojadinovic, O, Golinko, MS, et al, 2008, Growth factor and Cytokines in wound healing, wound reapir and regeneration, Wound Repair Reagen, Vol. 16(5), pp. 585-601

7. Budhy, TI, Wulandari, Erawati, \& Mooduto, Latief, 2007, Uji Sitotoksisitas 
Ekstrak Air Asam Jawa 5\% Terhadap Cell Line BHK 21, Indonesian Journal of Dentistry, pp.19

8. Freshney, R, 2011,Animal cell Culture , A practical approach, 6th edition, IRI, Press : Washington DC, pp.113-114

9. Ghantous, Y, 2017, Global Incidence and Risk Factors Of Oral Cancer, National Institutes of Health, pp. 1

10. Gibco, 2015, Cell Culture Basic Handbook, Thermo Fisher Scientific, pp.2.

11. Guha, N, Boffeta, P, Shangina, et al, 2007, Oral Health and Risk of Squamous Cell Carcinoma of the Head and Neck and Esophagus: Results of Two Multicentic Case- Control Studies, American Journal of Epidemiology, pp.1159-1160.

12. Harborne, JB, 1987, Metode Fitokimia, Penuntun Cara Modern Menganalisis Tumbuhan, Penerjemah: Kosasih P., Iwang S.Terbitn kedua, Bandung:Penerbit ITB, pp.152-153.

13. Istindiah, HN \& Auerkari, EL, 2001, Mekanisme Kontrol Siklus Sel (Suatu Tinjauan Khusus Peran Protein Regulator Pada Jalur Retinoblastoma (Rb) ), Jurnal Kedokteran Gigi Universitas Indonesia vol 8(1) pp.40

14. Kayanoki, Y, Fujii, J, Suzuki, K,et al, 1994, Suppression of Antioxidatve Enzym Expression by Transforming Growth Factor- $\beta 1$ in Rat Hepatocytes, The Journal of Biological Chemistry, pp.15488

15. Krisnadi, Dudi, 2015, Kelor Super Nutrisi.Pusat Informasi dan Pengembangan Tanaman Kelor Indonesia Lembaga Swadaya Masyarakat - Media Peduli Lingkungan(LSM-Mepeling), pp.812, 36-37,63-64.

16. Kumar S \& Pandey AK, Chemistry and Biological Activities of Flavonoids: An Overview, Review Article, The Scientific World Journal, Vol 2013, Article ID 162750, pp 1-16.

17. Kousholt, A, Menzel, T, \& Sorensen, C, 2012, Pathways for Genome Integrity in G2 Phase of the Cell Cycle, Biomolecules, pp. 2.

18. Laborde, E, 2010, Glutathine Transferase as mediators of Signalling Pathway Involved in Cell Proliferation and Cell Death, pp.3-4.

19. Loprinzi, C, Bensinger, W, \& Peterson, D, 2014, Understanding and Managing Chemotherapy Side Effects, Cancer Care, pp.4-7.
20. Ma'at, Suprapto, 2011,Teknik Dasar Kultur Sel, Surabaya: Airlangga University, pp.9-10

21. Marthur, B, 2005, Moringa oleifera, Treesforlife, pp.11

22. Provost, J, 1998, MTT Proliferatoin Assay Protocol.Investigating the Biochemistry \& Cellular Physiology of NHE1, Provost \& Wallert Research pp.15-16.

23. Putra, Wayan DP, Dharmayudha, Anak AGO, \& Sudimartini, LM, 2016, Identifikasi Senyawa Kimia Ekstrak Etanol Daun Kelor (Moringa oleifera $L$ ) di Bali, Indonesia Medicus Veterinus, pp.466-467.

24. Redha, Abdhi, 2010, Flavonoid:Struktur, Sifat Antioksidatif dan Peranannya dalam sistem biologis, Jurnal Belian vol 9, pp.197-199.

25. Ricci, P, 2008,Environmental and Health Risk Assessment and Management: Principles and Practices, Netherlands:Springer, pp.213.

26. Sayuti, Kesuma \& Yenrina, Rina, 2015, Antioksidan, alami dan sintetik, Padang:AU Press, pp.10-17

27. Saxena, M, Nema, R, \& Gupta, A, 2013, Phytochemistry of Medicinal Plants, Joural of Pharmacognosy and Phytochemistry, pp.168.

28. Shentilreja, P \& Kathiresan, K, 2015, In Vitro Cytotoxicity MTT Assay in Vero, HepG2 and MCF-7 Cell study of Marine Yeast, Journal of Applied Phamaceutical Science Vol.5, pp.081-082.

29. Srivastava, S\& Singh, S, 2004, Cell cycle arrest,apoptosis induction and inhibition of nuclear factor kappa B activation in antiproliferatic activity of benzyl isothiocyanate against human pancreatic cancer cells, Carcinogenesis:Departement of Pharmacology and University of Pittsburg Cancer Institute, pp.1701-1704

30. Tiara, 2010, Curcumin sebagai Terapi Pendamping untuk Kanker.Jurnal Medika Kedokteran Indonesia vol XXXV, pp.1-2.

31. Toma, A\& Deno, S, 2014, Phytochemistry and Pharmacological Activities of Moriga oleifera, Internatioinal Journal of Biological Chemistry, pp.223-227.

32. Veal, E, Toone, M, Jones, N, Morgan, B, 2002, Distinct Roles for Gluthatione STransferase in the Oxidative Stress Response in Schizosaccharomyces pombe, Journal of Biological Chemistry, pp.1. 
Jurnal Biosains Pascasarjana Vol. 17 (2015) pp

(C) (2015) Program Pascasarjana Universitas Airlangga, Indonesia

33. Warnakulasuriya, S, 2008, Global Epidemiology of Oral and Ooropharyngeal Cancer, Department of Oral Medicine and Experimental Oral Pathology, London:Elsevier, pp.309

34. Walton, R\& Toerbinejed, 2008, Prinsip dan Praktik Ilmu Endodonsia 3th ed, Jakarta:EGC, pp.15.

35. Yousef, A, 2011, Isothiocyanate Glycoside, Phytotherapy, pp. 1.

36. Yulianti, $\mathrm{T}, 2009$, Biofumigan Untuk Pengendalian Patogen Tular Tanah Penyebab Penyakit Tanaman Yang Ramah 